MAKING THE CUT 



\section{Making the Cut}

Hiring Decisions,

Bias, and the

Consequences

of Nonstandard,

Mismatched,

and Precarious

Employment

David S. Pedulla 
Copyright (๑) 2020 by Princeton University Press

Published by Princeton University Press

41 William Street, Princeton, New Jersey 08540

6 Oxford Street, Woodstock, Oxfordshire OX20 1TR

press.princeton.edu

All Rights Reserved

ISBN 978-0-691-17510-2

ISBN (e-book) 978-0-691-20007-1

British Library Cataloging-in-Publication Data is available

Editorial: Meagan Levinson and Jacqueline Delaney

Production Editorial: Jenny Wolkowicki

Jacket design: Chris Ferrante

Production: Erin Suydam

Publicity: Kate Hensley and Kathryn Stevens

Copyeditor: Joseph Dahm

This book has been composed in Adobe Text Pro and Gotham

Printed on acid-free paper. $\infty$

Printed in the United States of America

$\begin{array}{llllllllll}10 & 9 & 8 & 7 & 6 & 5 & 4 & 3 & 2 & 1\end{array}$ 
For Devah,

my academic inspiration

and

For Matt,

my inspiration in life 
